\title{
Pengolahan Berbagai Produk Berbahan Baku Ikan pada Kelompok Mitra Desa Binaan UMI
}

Etik Prihatin ${ }^{1}$, Muh. Haerdiansyah Syahnur ${ }^{2 *}$

Fakultas Ekonomi dan Bisnis, Universitas Muslim Indonesia, Makassar ${ }^{1,2}$ etik.prihatin@umi.ac.id ${ }^{l}$,haerdiansyah@umi.ac.id ${ }^{2 *}$

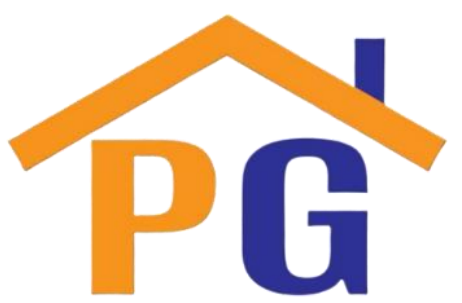

Riwayat Artikel

Diterima pada 17 November 2021

Revisi 1 pada 18 November 2021

Revisi 2 pada 30 November 2021

Revisi 3 pada 4 Januari 2022

Disetujui pada 5 Januari 2022

\begin{abstract}
Purpose: The aim of designing this $\mathrm{PkM}$ is to increase and develop the potential and economic capacity of the community, particularly in the villages that have received assistance from the Universitas Muslim Indonesia, to improve the overall well-being of the community. Another objective is to increase income and improve the well-being of rural communities during the period of recovery from the COVID-19 pandemic's economic impact.

Method: The method is carried out by providing socialization to housewives who are members of the Family Empowerment group of partner villages, processing assistance to making products made from fresh fish produced from natural resources in Desa Padingging, Kabupaten Takalar.
\end{abstract}

Results: The products are widely distributed, both in grocery stores backed by BUMDes and in traditional markets, as well as in the process of entering the Makassar souvenir shops that are characteristic of the city.

Conclusions: To promote the use of natural resources in Takalar Regency, which is rich in natural resources and particularly abundant in fresh fish, socialization activities relating to their utilization have been carried out. This is done to maximize the economic potential currently available for the production of superior processed fish products. As a result of the activities that have been carried out, it is expected that housewives and partner villages supported by Universitas Muslim Indonesia will be able to earn a living independently.

Keywords: Bahan baku dari ikan, Pengolahan produk

How to Cite: Prihatin, E., dan Syahnur, M, H. (2022). Pengolahan Berbagai Produk Berbahan Baku Ikan pada Kelompok Mitra Desa Binaan UMI. Yumary: Jurnal Pengabdian kepada Masyarakat, 2(2), 91-99.

\section{Pendahuluan}

Masyarakat di Desa Paddingnging Kecamatan Sanrobone Kabupaten Takalar mengalami kesulitan di bidang ekonomi yang meliputi tingkat pendapatan yang rendah, tingkat partisipasi yang rendah, dan kurangnya kemampuan bersaing dalam pengolahan sumber daya alam yang kesemuanya masih dapat diperbaiki kekurangannya. Padahal jika dimanfaatkan dengan baik, sumber daya alam khususnya ikan segar yang ada pada Desa Paddingging ini mampu membawa nilai tambah bagi perekonomian masyarakat desa, apalagi dalam masa pemulihan pandemi Covid-19 seperti saat ini. Selain itu, masalah pembangunan di bidang ekonomi belum ditangani secara memuaskan. Hal ini terlihat dari semakin banyaknya masyarakat yang hidup dalam kemiskinan di Indonesia, khususnya di pedesaan (Sunyoto, 2004). Oleh karena itu, pembangunan ekonomi menjadi fokus utama dari inisiatif pengentasan kemiskinan. 


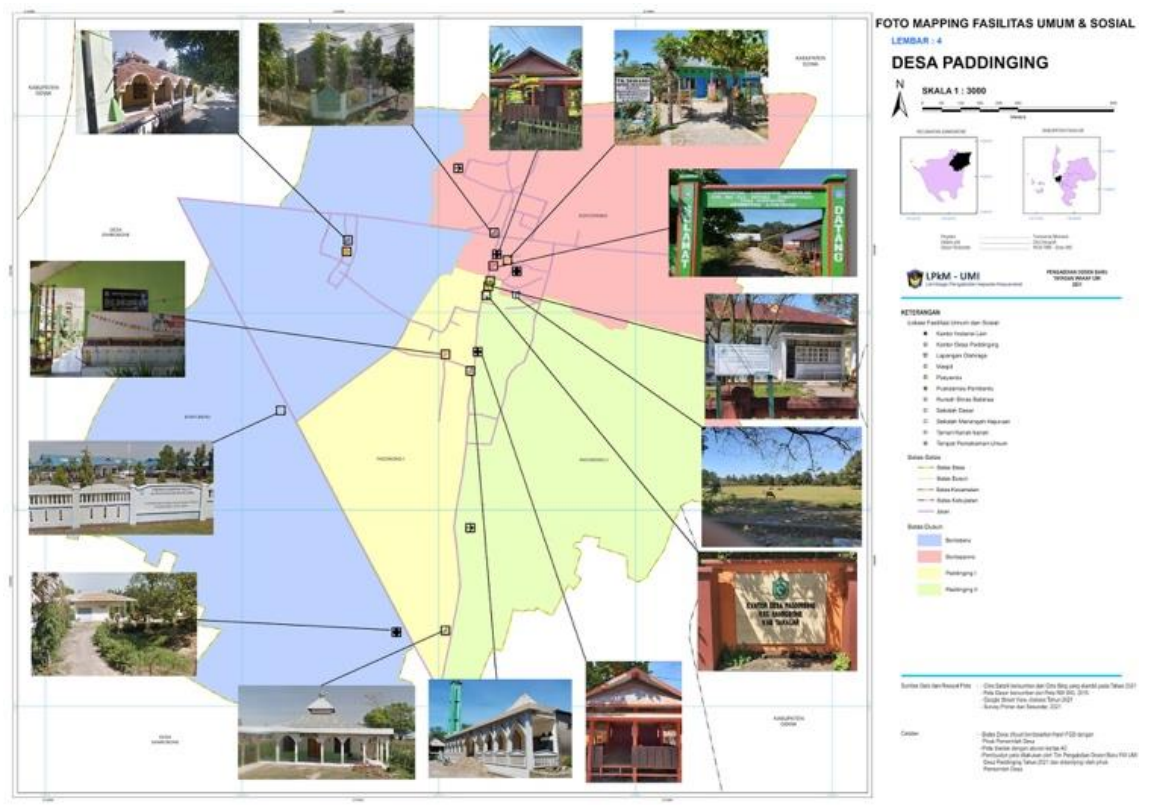

Gambar 1. Mapping Foto Desa Paddingnging

Desa Paddingging merupakan salah satu desa yang terletak di Kecamatan Sanrobone dengan luas wilayah $336.37 \mathrm{~km}^{2}$. Desa Paddinging merupakan satu-satunya desa di Kabupaten Takalar yang terletak di jalur pengembangan kota Ma'minasata dan paling mudah dijangkau dari Ibu Kota Provinsi Sulawesi Selatan. Desa ini merupakan satu-satunya desa di Kabupaten Takalar yang terletak di jalur pengembangan kota Ma'minasata. Jarak antara Ibu Kota Kecamatan Sanrobone dan Ibu Kota Kabupaten Takalar adalah 3 kilometer, dan jarak antara Ibu Kota Sanrobone dan Takalar adalah 3,5 kilometer. Secara keseluruhan, topografi Desa Paddinging adalah datar dengan sawah, kebun, dan laut yang mengelilinginya di semua sisi, dan ketinggian rata-rata sekitar 100 meter (328 kaki) di atas permukaan laut. Desa Paddinging terbagi menjadi 4 (empat) wilayah dusun, yaitu Dusun Paddinging 1, Dusun Paddinging 2, Dusun Bontopanno, dan Dusun Bontoberu, jika ditinjau dari struktur administrasinya. Penduduk yang mendiami desa Paddingnging berjumlah 1.750 jiwa dimana 824 jiwa laki-laki dan 926 jiwa adalah perempuan (SEJARAH DESA PADDINGING, n.d.)

Ketimpangan pertumbuhan penduduk antara pedesaan dan perkotaan harus diwaspadai karena jika tidak diantisipasi sejak dini dapat menimbulkan masalah yang kompleks dan berkepanjangan, khususnya di bidang sosial (Chikmawati, 2019). Demikian pula dengan potensi sumber daya manusia Desa Paddingnging, sangat penting untuk memberikan tambahan pengetahuan dan keterampilan. Selain memberikan wawasan juga memberikan tambahan sumber pendapatan dan konsumsi pangan.

Program kegiatan pengabdian kepada masyarakat dosen Universitas Muslim Indonesia bekerja sama dengan Desa Binaan Pemberdayaan Kesejahteraan Keluarga (PKK) di Desa Paddingnging dengan memberikan wawasan kepada ibu-ibu PKK serta membekali mereka dengan pengetahuan dan keterampilan yang diperlukan untuk mengolah dan memberi nilai tambah pada produk. Pada akhirnya mereka diharapkan memiliki keterampilan dalam mengolah ikan yang merupakan salah satu ciri khas produk yang dihasilkan di Desa Paddingnging Kabupaten Takalar. Selain itu, dengan membuat produk olahan berbahan ikan segar juga dapat membantu untuk meningkatkan konsumsi ikan di daerah Desar Paddingnging, hal tersebut akan memberi dampak positif terutama dalam membantu memenuhi angka kecukupan gizi yang diberi atau diperoleh dari konsumsi ikan laut yang segar.

Proses pembuatan produk olahan ikan ini berbeda dengan proses pembuatan produk olahan ikan lainnya. Proses pembuatan produk ini menggunakan proses alami yang hanya menggunakan bahan ikan segar dan tidak menggunakan bahan pengawet dalam pembuatannya. Keunggulannya, selain hanya membutuhkan teknologi dan peralatan dasar yang sederhana, juga memanfaatkan bahan ikan 
segar yang melimpah yang dapat diperoleh dengan mudah dari pesisir pantai desa Paddingnging di Kabupaten Takalar yang jaraknya hanya beberapa kilometer. Hal lain adalah bahwa proses yang diikuti oleh Kelompok Mitra di Desa Paddingnging, Kabupaten Takalar sangat sederhana untuk dikembangkan, memungkinkan mereka untuk menjadi wirausahawan baru yang pada gilirannya akan meningkatkan pendapatan mereka dan sebagai hasilnya, perekonomian masyarakat akan meningkat. Produk olahan yang berbahan dasar ikan Takalar segar ini bisa dijual di pasar dan toko yang telah didirikan oleh Pemerintah Desa Paddingnging di Kabupaten Takalar. Produk olahan berbahan dasar ikan segar ini belum banyak diproduksi oleh masyarakat desa, padahal produk-produk tersebut banyak yang sejenis. Hal ini terutama berlaku dalam hal proses manufaktur yang merupakan area di mana terdapat potensi pertumbuhan dan perkembangan yang signifikan. Sehingga perlu untuk memperkenalkan produk olahan ikan segar ini kepada masyarakat, khususnya kelompok mitra agar dapat memberikan dampak positif bagi perkembangan usaha dan peningkatan pendapatan masyarakat di Desa Paddingnging Kabupaten Takalar.

Semua bentuk usaha yang ada, seperti UKM, koperasi, dan sebagainya, dapat beroperasi dan berpartisipasi aktif dalam kegiatan ekonomi individu. Usaha kecil dan menengah (UKM) merupakan salah satu jenis usaha yang berkembang dalam menjalankan perekonomian rakyat selama ini karena menjalankan fungsi kerakyatan, yaitu: (1) membangun dan mengembangkan potensi dan kapasitas ekonomi masyarakat dalam rangka peningkatan kesejahteraan; (2) mengembangkan kemandirian usaha dan perluasan kesempatan kerja agar berdampak pada perubahan fundamental ekonomi keluarga; dan (3) meningkatkan pendapatan dan kesejahteraan masyarakat. Berkaitan dengan hal tersebut, perlu dikaji dan ditelaah sejauh mana masyarakat tertentu, baik perkotaan maupun pedesaan, perlu dilibatkan untuk memaksimalkan potensi ekonomi dan meningkatkan kualitas sumber daya manusia tersebut. Menurut Bank Dunia, pemberdayaan adalah suatu proses pembangunan yang memerlukan kemandirian, kemandirian dari orang lain, dan memperkuat posisi tawar kelas bawah terhadap kekuatan penindas di segala bidang dan sektor kehidupan (Eko et al., 2014).

Program pengabdian kepada masyarakat yang dilakukan di Desa Paddingnging, Kecamatan Sanrobone, Kabupaten Takalar diharapkan mampu membantu meningkatkan keterampilan pengolahan berbagai produk unggulan berbahan ikan yang mana merupakan sumber daya alam yang melimpah yang dimiliki oleh warga Desa Paddingnging, selain sebagai sumber bahan makanan, juga dapat menjadi salah satu sumber yang menambah pendapatan. Hasil penelitian Arfianto \& Balahmar (2014) menunjukkan bahwa kehadiran pemberdayaan masyarakat dalam pembangunan ekonomi desa berpotensi meningkatkan kesejahteraan masyarakat desa sehingga mereka dapat hidup dengan puas dengan apa yang mereka miliki selama ini. Demikian pula peran pemerintah dalam membantu pemberdayaan masyarakat meliputi pembinaan, sosialisasi, dan bentuk bantuan lainnya. Hal ini sangat bermanfaat bagi masyarakat dalam hal meningkatkan situasi ekonomi keluarga mereka.

Program kegiatan pengabdian kepada masyarakat yang akan dilakukan di Desa Paddingnging Kecamatan Sanrobone, Kabupaten Takalar ini melalui modal kemitraan universitas yang kegiatannya adalah pengolahan berbagai produk berbahan ikan dengan pertimbangan: 1) Memberdayakan potensi Pemberdayaan Kesejahteraan Keluarga (PKK) melalui aksi program pengolahan berbagai produk berbahan dasar ikan yang dapat memberi nilai ekonomi dan sosial, seperti halnya Agustina (2020) yang memberdayakan keterampilan melalui teknik pengolahan pada ibu-ibu asawisma dan karang taruna. 2) Kegiatan pengabdian kepada masyarakat ini perlu dilakukan untuk menjawab tantangan dan permasalahan yang dihadapi masyarakat terutama masyarakat Desa Paddingnging Kecamatan Sanrobone, Kabupaten Takalar yaitu tantangan di bidang ekonomi. 3) Membangkitkan minat dan gairah masyarakat Desa Paddingnging Kecamatan Sanrobone, Kabupaten Takalar sebagai mitra untuk mengembangkan unit usaha kecil-menengah (UKM) berbasis warga desa, sekaligus diharapkan dapat menjadi sumber pendapatan baru bagi warga desa binaan UMI.

Berdasarkan uraian di atas, maka kegiatan pengabdian kepada masyarakat ini, diharapkan dapat memberikan jawaban atas permasalahan yang harus dijawab: (1) Program pengabdian kepada masyarakat mengenai pengolahan berbagai produk berbahan dasar ikan pada masyarakat Desa 
Paddingnging Kecamatan Sanrobone, Kabupaten Takalar belum pernah dilakukan namun memiliki potensi untuk meningkatkan keterampilan, nilai konsumsi, dan pendapatan. (2) Hasil pengolahan berbagai produk berbahan dasar ikan akan mengalami kendala, terutama dari aspek pemasaran namun dengan memanfaatkan teknologi, khususnya teknologi informasi yang menjadi semakin penting dalam dunia globalisasi saat ini. Pemasaran dapat dilakukan dengan memanfaatkan media sosial yang berpotensi menjadi platform yang menguntungkan dan efektif dalam mengembangkan bisnis (As' ad et al., 2019).

\section{Metode}

Untuk membantu kelompok mitra dalam mengatasi kendala, program PkM ini membutuhkan pendekatan dan metode baru yang mana program dilaksanakan secara partisipatif dengan melibatkan masyarakat dalam proses perancangan, perencanaan, pelaksanaan, dan evaluasi program pembangunan desa. Dengan kata lain, pembangunan desa secara partisipatif merupakan pembangunan desa yang melibatkan masyarakat desa pada setiap tahapan proses, mulai dari perencanaan program dan pengambilan keputusan hingga pelaksanaan program serta pemantauan dan evaluasi hasil desa (SANGIAN et al., 2018). Metode dan pendekatan yang digunakan adalah sebagai berikut:

\section{Pendekatan penyuluhan}

Metode penyuluhan adalah salah satu metode yang telah banyak dikembangkan untuk tujuan mentransfer inovasi. Teknik konseling ini harus digunakan dengan anggota kelompok. Artinya, mindset harus diubah sebelum melaksanakan program PkM. Konseling dapat berbentuk komunikasi interpersonal atau tatap muka. Selain itu, dapat juga berperan sebagai sarana sosialisasi program. Teknik ini dianggap efisien dan efektif untuk mengirimkan pesan program. Kegiatan penyuluhan berlangsung selama satu hari dan kami/penulis menerima tanggapan positif dari para peserta. Hal ini ditunjukkan dengan banyaknya peserta yang memenuhi balai desa dengan antusias dengan tetap menjaga jarak fisik satu sama lain.

\section{Metode pelatihan}

Seiring dengan metode penyuluhan, metode pelatihan juga sering digunakan. Metode pelatihan yang dikembangkan untuk program PkM ini adalah sebagai berikut:

1. Pelatihan teknis dilakukan melalui pengolahan berbagai produk ikan di masyarakat Desa Paddingnging, Kecamatan Sanrobone, Kabupaten Takalar, dimulai dari pemilihan bahan baku yang akan digunakan, pencampuran, dan akhirnya mendapatkan produk dengan nilai jual yang tinggi.

2. Edukasi kemasan. Kemasan merupakan salah satu nilai jual produk. Teknik pengemasan dan pemahaman akan pentingnya pengemasan sangat penting bagi kelompok mitra untuk mengembangkan beragam produk olahan berbahan dasar ikan yang mereka hasilkan. Dengan teknik pengemasan yang efektif, akan dapat meningkatkan nilai jual produk yang dijual, sehingga meningkatkan volume penjualan dan pada akhirnya meningkatkan pendapatan kelompok mitra.

3. Pelatihan non-teknis diberikan untuk menjawab tantangan analisis bisnis kelompok mitra. Sejalan dengan itu, pelatihan non-teknis akan mencakup kegiatan materi sebagai berikut, yakni manajemen kewirausahaan kelompok, khususnya pemasaran dan pembukuan. Serta, penguatan kelembagaan bagi kelompok mitra.

\section{Pendekatan \& pendampingan}

Untuk mengembangkan program PkM bagi kelompok mitra, pembuatan aneka produk olahan ikan masyarakat Desa Paddingnging Kecamatan Sanrobone, Kabupaten Takalar dilakukan dengan tujuan mengembangkan usaha, maka pendekatan yang paling tepat adalah belajar sambil bekerja. (Dewi et al., 2021) Pendekatan ini akan dikembangkan setelah pelatihan, di mana kelompok akan mempraktikkan apa yang mereka pelajari sebelumnya dengan membuka atau mengembangkan usaha produk ikan dan tepung terigu.

1. Group Instruction, Proses pembelajaran dalam kelompok ini akan berulang. Mereka pada dasarnya telah menciptakan produk yang dapat dipasarkan selama proses pembelajaran mereka 
di grup ini. Ini disebut sebagai Learning By Doing, atau belajar sambil bekerja. Proses belajar kelompok ini akan terus didampingi oleh pendamping. Kegiatan belajar kelompok berfungsi sebagai awal dari bisnis yang akan dikembangkan oleh setiap anggota kelompok. Untuk memaksimalkan pembelajaran kelompok, perlu dipelajari bagaimana melakukan pembukuan agar kelompok dapat menganalisis usaha yang dilakukan.

2. Pemasaran dan pengolahan aneka produk berbahan dasar ikan pada masyarakat Desa Paddingnging Kecamatan Sanrobone Kabupaten Takalar. yang diperoleh selama pembelajaran kelompok mitra merupakan produk awal kelompok mitra dalam program PkM. Produk yang dihasilkan dapat dipasarkan, dan kelompok mitra mempertahankan semua hasil penjualan. (Fithri et al., 2017) Selain menguasai teori-teori yang berkaitan dengan perkembangan media promosi dan pemasaran memanfaatkan perdagangan elektronik, warga Desa Paddingnging mendapatkan wawasan tentang penerapan perdagangan elektronik dalam rangka kegiatan promosi dan pemasaran produk melalui kegiatan langsung. pengalaman.

3. Pembinaan dan evaluasi, yang dilakukan secara berkesinambungan untuk mengetahui sejauh mana keberhasilan masing-masing kelompok mitra. Pembinaan dilakukan dengan melakukan diskusi pada setiap tahapan kegiatan program PkM. (Wibowo, 2019) Diskusi dilakukan untuk mendapatkan masukan dari peserta, dan dengan masukan tersebut kelemahan kelompok dapat diperbaiki sehingga menghasilkan program yang lebih sempurna. Sedangkan evaluasi dilakukan dalam 3 (tiga) tahap, yaitu sebagai berikut: evaluasi awal, evaluasi tengah semester, dan evaluasi akhir. Hal-hal yang dianggap perlu perbaikan selama evaluasi harus ditindaklanjuti dengan kelompok kegiatan sehingga solusi yang dipilih disepakati bersama oleh fasilitator dan kelompok mitra. (Nastiti et al., 2021) Setiap kelompok mengimplementasikan hasil kesepakatan bersama ini.

\section{Hasil dan Pembahasan}

Pengabdian masyarakat ini berlangsung pada hari Rabu, 15 September 2021 mulai pukul 09.30 hingga 14.00 WITA. Kegiatan pengabdian ini berlokasi di Kantor Desa Paddingnging, Kecamatan Sanrobone, Kabupaten Takalar, Sulawesi Selatan, Indonesia. Kegiatan dibuka oleh Kepala Desa Paddingging beserta jajarannya, kegiatan ini diikuti oleh 18 ibu rumah tangga perwakilan pengurus PKK Desa Binaan Desa Padingnging Kabupaten Takalar. Selain itu, kepala desa dan jajaran pimpinan Desa Paddingnging turut serta dalam kegiatan ini hingga akhir kegiatan dilaksanakan.

Pertemuan pertama berlangsung di Desa Paddingnging, Kecamatan Sanrobone, Kabupaten Takalar, dimana pembicara bertemu dengan anggota PKK. Kegiatan dilakukan secara interaktif, dengan banyak diskusi dan tanya jawab. Tujuan diskusi adalah untuk memastikan aspirasi bisnis dan hambatan masuk mereka. Dengan adanya diskusi ini, diharapkan pada pertemuan berikutnya, para peserta mendapatkan pelatihan dan bimbingan yang disesuaikan dengan kebutuhan spesifik mereka. Disimpulkan dari diskusi bahwa para peserta sangat antusias untuk memulai bisnis baru. Mereka sebelumnya telah bekerja di berbagai industri, termasuk pertanian dan perikanan. 


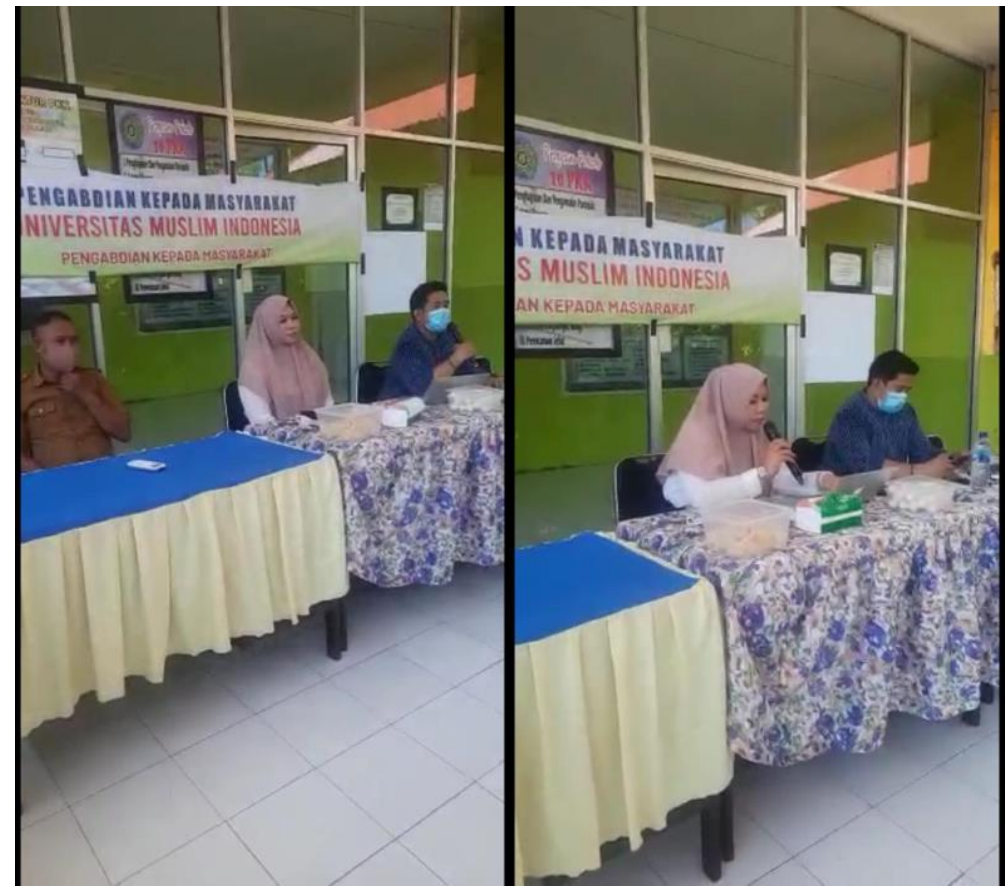

Gambar 2. Diskusi dan Tanya Jawab Mengenai Kebutuhan dari Peserta Pendampingan PkM

Pertemuan selanjutnya adalah presentasi tentang pentingnya berwirausaha dalam memulai usaha kecil. Kegiatan diawali dengan demonstrasi cara memulai usaha. Selanjutnya dibahas manfaat pemanfaatan hasil laut, khususnya ikan segar; peserta mengajukan beberapa usulan jenis usaha yang akan ditekuni, antara lain: 1) Usaha Jajanan atau 2) Usaha Kerajinan Tangan. Selain itu, diadakan pula sesi diskusi dan tanya jawab mengenai proposal bisnis yang dianggap menarik dan dapat diimplementasikan oleh peserta. Setelah diskusi, diputuskan pada pertemuan berikutnya ibu-ibu PKK akan belajar membuat produk berbahan dasar ikan.

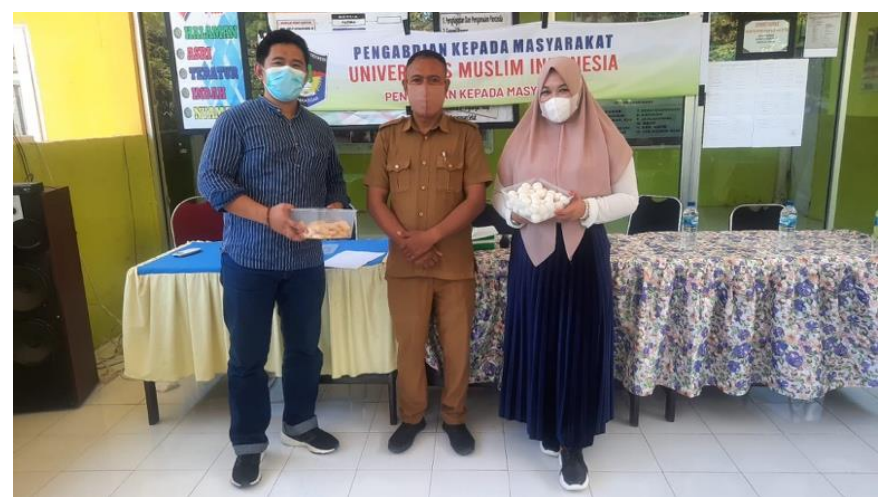

Gambar 3. Presentasi Hasil Produk Olahan kepada Perwakilan Kepala Desa Paddingnging, Kab Takalar

Pada pertemuan terakhir, peserta belajar bagaimana membuat produk, mulai dari persiapan bahan, pengolahan adonan, dan menggoreng adonan hingga menghasilkan produk yang layak untuk dikonsumsi. Tahapan pembuatannya, khususnya: 1. Siapkan bahan bakso dan nugget ikan, 2. Persiapan adonan, dan 3. Pembentukan adonan.

Setelah narasumber mendemonstrasikan proses pembuatan bakso dan nugget ikan, para peserta diminta untuk mempraktekkan sendiri pembuatan produk tersebut. 


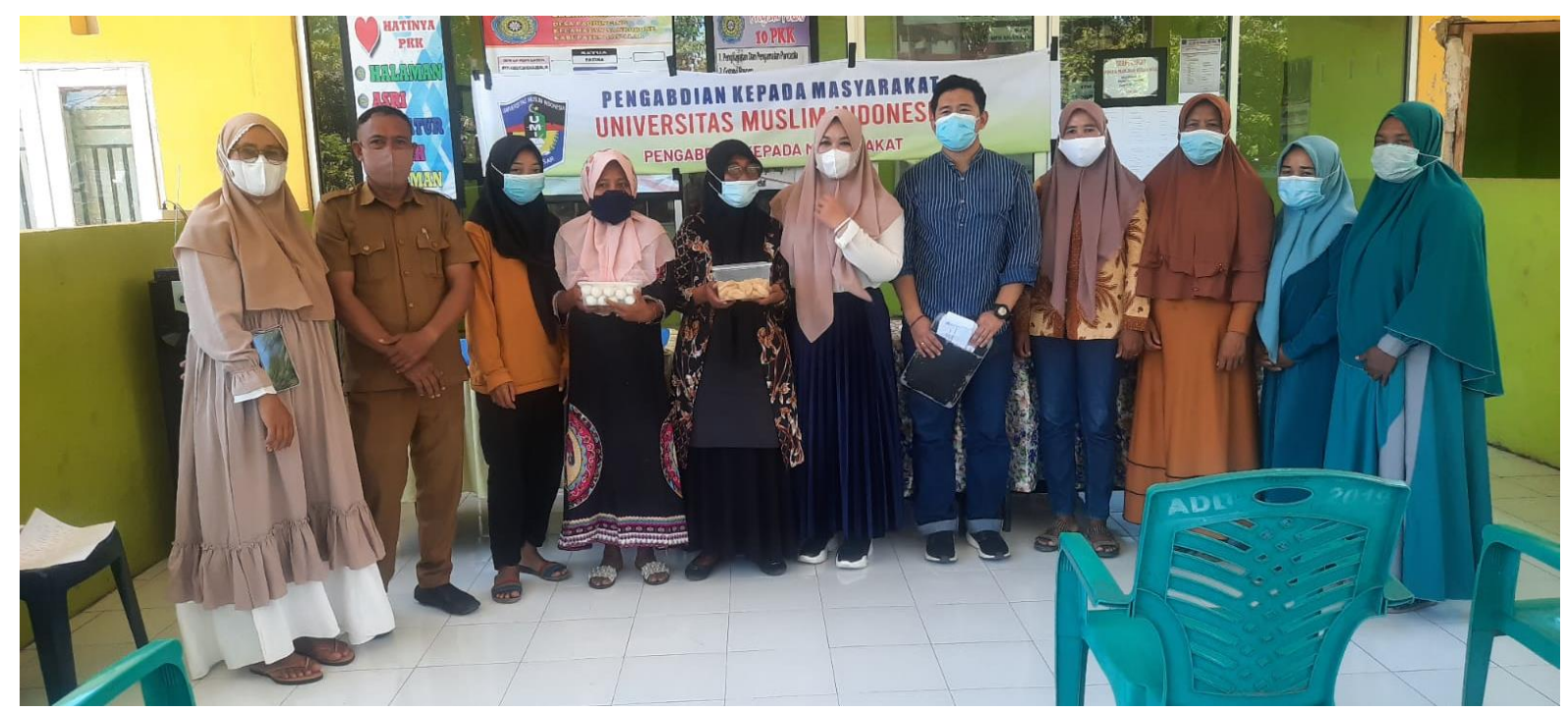

Gambar 4. Proses Pemberian Produk kepada Perwakilan dari Peserta

Di akhir kegiatan, peserta diminta untuk mengisi kuesioner evaluasi kegiatan untuk menilai tingkat pengetahuan mereka tentang materi yang diberikan. Evaluasi kegiatan merupakan hal yang penting agar mengetahui tingkat pemahaman dari peserta sebelum dan setelah melakukan kegiatan, hal ini juga dilakukan oleh (Yuliansyah et al., 2020) dan (Sayuti et al., 2021) dalam melakukan proses akhir pada kegiatan PkM. Para peserta diminta untuk menilai kegiatan yang mereka ikuti. Evaluasi menunjukkan bahwa peserta mampu menerima materi. Selain itu, kuesioner evaluasi yang dibagikan kepada peserta setelah mengikuti kegiatan pelatihan mengevaluasi tiga poin: pembicara, materi, dan alur acara secara keseluruhan. Peserta diminta untuk menilai diri mereka sendiri pada skala 1 sampai 5 .

Kami Tim PkM telah memberikan materi tentang nilai inovasi yang dapat diterapkan pada hal apapun, termasuk pada kekayaan alam yang melimpah di Desa Paddingnging Kabupaten Takalar khususnya ikan segar. Motivasi berwirausaha juga dapat digunakan untuk mengelola suatu produk melalui penggunaan e-commerce (sebagai contoh), terutama mengingat distribusi fasilitas teknologi dan informasi yang sudah relatif merata di desa Paddingnging, Kabupaten Takalar. Seperti pada hasil pengabdian yang dilakukan oleh (Andi et al., 2021) yang membantu masyarakat untuk memasarkan penjualan melalui media pemasaran melalui media sosial.

Kendala yang ditemui di lapangan, di mana kami memelajari beberapa hal, antara lain anggapan bahwa hasil penyuluhan ini akan cukup sulit dicapai karena motivasi masyarakat untuk berwirausaha masih rendah, oleh karena itu kegiatan seperti ini harus dilakukan secara berkala dan hasil yang diperoleh dipantau setiap saat. Materi yang kami berikan juga harus mempertimbangkan tingkat penerimaan masyarakat desa, yang artinya sebisa mungkin dalam proses penyampaian informasi harus disertai dengan bahasa yang santai dan tidak membatasi, bahkan dapat dipadukan dengan Bahasa khas daerah Makassar, seperti bahasa yang digunakan masyarakat sehari-hari. Selain itu, dalam menentukan waktu kegiatan seminar, terkadang peserta kegiatan dan tim pelaksana tidak bersamaan, dan pada saat pelaksanaan kegiatan, ada kalanya kegiatan penyuluhan sedikit terkendala oleh kestabilan jaringan internet ketika kami mencoba memvisualisasikan metode pengolahan ikan yang yang kami adaptasi melalui internet.

\section{Kesimpulan dan Saran}

Bakso dan nugget yang terbuat dari produk ikan olahan adalah pilihan bisnis rumahan yang layak bagi pengusaha kecil yang ingin memperluas operasi mereka saat ini atau memulai yang baru dari kenyamanan rumah mereka sendiri. Salah satu keunggulan dari usaha pengolahan ikan ini adalah bahan bakunya dapat dibuat dari berbagai jenis ikan yang

2022 | Yumary: Jurnal Pengabdian kepada Masyarakat/ Vol 2 No 2, 91-99 
banyak terdapat di Kabupaten Takalar, Sulawesi Selatan, dan menjadi salah satu kekayaan alam yang sangat berharga di daerah tersebut. Cakalang misalnya, merupakan jenis ikan yang melimpah, terjangkau serta banyak dijual di pasar-pasar tradisional di wilayah kabupaten Takalar. Secara umum kegiatan ini dinilai bermanfaat bagi ibu-ibu PKK di Desa Paddingnging, Kabupaten Takalar. Peserta diharapkan mampu menyiapkan produk olahan ikan yang khas daerahnya sebagai hasil dari keikutsertaan dalam kegiatan ini. Strategi pemasaran atau alternatif usaha rumahan seperti membuat keripik, memasukkan cabai ke dalam produk seperti Bon Cabe, atau memanggang kue tradisional ala Takalar diharapkan menjadi fokus kegiatan selanjutnya berdasarkan temuan evaluasi. Secara umum, pengolahan berbahan ikan yang telah didampingi dari tim PkM Universitas Muslim Indonesia ini dapat diimplementasikan secara konkrit dan jelas bagi kelompok ibu PKK di Desa Paddingnging, Kabupaten Takalar, Sulawesi Selatan dan dapat menjadi pemasukan tambahan bagi mereka.

\section{Ucapan terima kasih}

Dalam kapasitas kami sebagai tim pengabdian masyarakat dari Fakultas Ekonomi dan Bisnis Universitas Muslim Indonesia, kami mengucapkan terima kasih yang sebesar-besarnya kepada Lembaga Pengabdian kepada Masyarakat (LPkM) UMI yang telah memberikan dukungan baik materil maupun non materil sehingga terselenggaranya program ini dengan baik. Kegiatan berjalan dengan lancar. Selain itu, kami haturkan salam hangat dan terima kasih kepada jajaran pimpinan Desa Paddingnging, Kecamatan Sanrobone, Kabupaten Takalar, Sulawesi Selatan yang telah mendukung program kami, menyambut dan memberikan banyak bantuan kepada tim.

\section{Referensi}

Agustina, Y. (2020). Peningkatan keterampilan dan pendapatan ibu-ibu Dasawisma dan Karang Taruna melalui kerajinan pengolahan barang sisa (Increasing the skills and income of the women of Dasawisma and Karang Taruna by processing waste goods). Yumary: Jurnal Pengebdian Kepada Masyarakat, 1(2), 69-79.

Andi, K., Dharma, F., \& Gamayuni, R. R. (2021). Pelatihan Peningkatan Kualitas Produk dan Pemasaran Usaha Bubuk Biji Salak di Desa Sungai Langka, Kabupaten Pesawaran. Yumary: Jurnal Pengabdian Kepada Masyarakat, 1(4), 203-209.

Arfianto, A. E. W., \& Balahmar, A. R. U. (2014). Pemberdayaan Masyarakat dalam Pembangunan Ekonomi Desa. JKMP (Jurnal Kebijakan Dan Manajemen Publik), 2(1), 53-66.

As' ad, A., Syahnur, H., \& Arumbarkah, M. (2019). Pelatihan Motivasi dan Kewirausahaan Bagi Warga Desa. Jurnal Pengabdian Bina Ukhuwah, 1(2), 8-15.

Chikmawati, Z. (2019). Peran BUMDes dalam meningkatkan pertumbuhan ekonomi pedesaan melalui penguatan sumber daya manusia. Jurnal Istiqro, 5(1), 101-113.

Dewi, R., Nasaruddin, F., \& Rosada, I. (2021). PKM Pengolahan Kacang Hijau Kelompok Perempuan Di Desa Bontolangkasa Kecamatan Bontonompo Kabupaten Gowa. Jurnal Pengabdian Masyarakat Kreatif, 7(2), 19-30.

Eko, S., Khasanah, T. I., Widuri, D., Handayani, S., \& Handayani, N. (2014). Desa membangun indonesia. FPPD. Yogyakarta.

Fithri, D. L., Utomo, A. P., \& Nugraha, F. (2017). Pemanfaatan E-Commerce Populer Populer untuk Optimalisasi Pemasaran Produk pada Kube Bordir Kurnia Desa Demangan Kudus. Simetris: Jurnal Teknik Mesin, Elektro Dan Ilmu Komputer, 8(2), 819-824.

Nastiti, R., Norbaiti, N., Akbar, M., \& Goenadhi, L. (2021). Pembinaan Desain Produk Amplang Ikan sebagai Alternatif Usaha Rumahan bagi Ibu-Ibu PKK Desa Terantang, Barito Kuala. PengabdianMu: Jurnal Ilmiah Pengabdian Kepada Masyarakat, 6(6), 604-608.

Sangian, D., Dengo, S., \& Pombengi, J. (2018). Pendekatan Partisipatif Dalam Pembangunan Di Desa Tawaang Kecamatan Tenga Kabupaten Minahasa Selatan. JURNAL ADMINISTRASI PUBLIK, 4(56).

Sayuti, M., Hismayasari, I. B., Supriatna, I., \& Abadi, A. S. (2021). Pendampingan Masyarakat di Kampung Salak, Kota Sorong: Pelatihan Teknik Pembenihan Ikan Lele Secara Buatan. Yumary: Jurnal Pengabdian Kepada Masyarakat, 1(4), 173-181. 
Sejarah Desa Paddinging. (n.d.). Retrieved November 17, 2021, from http://desapaddinging.blogspot.com/2017/02/sejarah-desa-paddinging.html

Sunyoto, U. (2004). Pembangunan dan Pemberdayaan Masyarakat, Yogyakarta. Pustaka Pelajar.

Wibowo, A. (2019). Pemberdayaan Petani Singkong Desa Tumpakrejo Kalipare Malang Melalui Inovasi Produk Emping Singkong. At-Tamkin: Jurnal Pengabdian Kepada Masyarakat, 2(2), $61-68$.

Yuliansyah, Y., Dewi, F. G., \& Amelia, Y. (2020). Pelatihan Standar Akuntansi Pesantren dalam penyusunan laporan keuangan bagi staf keuangan pondok pesantren. Yumary: Jurnal Pengabdian Kepada Masyarakat, 1(1), 11-17. 